\title{
Moslem Sculptor \\ (Negotiation of Sculptor at Prumpung Magelang Towards The Doctrine of Sculpting's Prohibition on Islam)
}

\author{
Muh Zuhri \\ Institut Agama Islam Negeri Salatiga, Indonesia \\ Email:muh.zuhri@yahoo.co.id \\ Ahmad Rafiq \\ Universitas Islam Negeri Sunan Kalijaga Yogyakarta, Indonesia \\ Email: ahmad.rafiq@uin-suka.ac.id \\ Ahmad Mustofa \\ Sekolah Tinggi Agama Islam Al Husain Magelang, Indonesia \\ Email: mustofa.ahmad8@gmail.com
}

\begin{abstract}
Normatively, Islamic doctrine prohibits figurative art in the form of sculpture or painting. The prohibition actually comes not from the Koran but from various narrations of the Prophet's hadith. However, it has been transformed into an orthodox doctrine for its adherents. This research does not aim to find the essential meaning of the hadith text which prohibits figurative art, but to find out how the Moslem sculptors, who live at Prumpung Magelang area, respond and negotiate toward it, so in the end they decided to compromise with their profession as a sculptor. Reception theory is used in this study to map the creative reasoning model of Moslem sculptors when negotiating with texts. Through the reception approach, and field data collection through in-depth interviews with several informants consisting of Muslim sculptors at Prumpung Magelang, this research concludes that the existence of the statue, according to the perspective of the Moslem sculptors at Prumpung Magelang is merely works of art so that in existence there are no theological problems.
\end{abstract}

Keywords: Orthodoxy, Moslem Sculptor, Negotiation and Reception

Abstrak
Secara normatif, doktrin Islam melarang seni figuratif baik berupa seni patung

Volume 23, Nomor 1 (2021) 
Muh Zuhri, Ahmad Rafiq, Ahmad Mustofa

atau lukisan. Larangan tersebut sebenarnya bukan berasal dari Alquran, melainkan dari berbagai riwayat hadits Nabi. Namun kemudian di kalangan umat Islam, larangan yang berasal dari teks-teks hadis tersebut telah berubah menjadi doktrin yang bersifat ortodoks. Penelitian ini tidak bertujuan untuk menemukan makna esensial dari teks hadits yang melarang seni figuratif, namun bertujuan untuk mengetahui bagaimana para pematung muslim yang tinggal di kawasan Prumpung Magelang merespon dan bernegosiasi terhadapnya, sehingga pada akhirnya mereka memutuskan untuk berkompromi dengan profesi mereka sebagai pematung. Teori resepsi digunakan dalam penelitian ini untuk memetakan model penalaran kreatif pematung muslim saat bernegosiasi dengan teks. Melalui pendekatan resepsi, dan pengumpulan data lapangan melalui wawancara mendalam dengan beberapa informan yang terdiri dari pematung muslim di Prumpung Magelang, penelitian ini menyimpulkan bahwa keberadaan patung menurut perspektif pematung muslim di Prumpung Magelang hanyalah karya seni rupa. seni sehingga dalam keberadaannya tidak ada masalah teologis.

Kata Kunci: Ortodoksi, Pemahat Muslim, Negosiasi dan Resepsi

\section{Introduction}

As a doctrine, Islam has a unique relationship with culture. This uniqueness is appear from dialectics and negotiations that occur between two different elements within Moslems, namely (1) religious entities originating from sacred texts (al-Qur'an - hadith), and (2) cultural entities which originates from the creativity and productivity of human reason so that is positioned in a profane area. Sometimes, the relationship that is often confronted, creates polemics in society and even creates a negative stigma for people who intensely interact with certain traditions and cultures. This is due to the public narrative that more often puts the two entities confrontational rather than put down them side by side so as to create a harmonious relationship (Mustofa 2021, ii).

Regarding the interaction between religious doctrine and culture, as mentioned above, Islam has a unique relationship with art, especially drawing and sculpture (figurative art). Normatively based on various hadith reports, the scholars have agreed to prohibit the existence of images and statues that resemble living things (Aș-Ṣābūnī 1981, II/405), both in the public or private areas. For example, an editorial hadith narrated by Ibn Abbas, that one day he was offered a picture of living things by a person who works as a painter, but he refused the painting while advising that The Prophet PBUH prohibits all kinds of paintings and sculptures in the form of living things, if you want to continue working as a painter or sculptor, you should choose objects other than living things (al-'Ainy Al-Hanafiy n.d., XVIII/159). 
Prohibition of images and statues in the Islamic tradition gives to the thought of iconophobia, which is an understanding that refers to an 'aversion' towards the existence of images or statues in the form of living things (Caviness 2002, 119). At the extreme level, this thought gave to the idea of iconoclasm, namely the idea of anti-figurative art (images and sculptures in the form of living things) by destroying various kinds of images and statues (Caviness 2002, 119). At the same time, iconophobia also create an anti-figurative idea but in a more moderate dosage, namely the idea of an-iconism. In principle, this idea has something in common with iconoclasm, namely both rejecting the existence of figurative art, but not by means of violence and destruction, as the iconoclasm movement. The idea of an-iconism chooses to avoid art products that have figurative elements, but still productive in art by sponsoring and at the same time pioneering the emergence of works of art in any form that focus on objects other than living figures (Soganci and Ismail 2004,1). In turn, the idea of aniconism make a flow of non-figurative art with its own style that characterizes Islamic art, namely ornamentation and calligraphy (Komaroff and Allen 1991, 4).

However, in certain conditions the doctrine of painting and sculpture in a figurative form does not always work as it should. A village in Magelang Regency, precisely in Prumpung Tamanagung Muntilan, there is an andhesite stone carving industry center which produces amazing statues so that it becomes a destination for domestic and foreign tourists. The village which served as the work place for hundreds of sculptors is very interesting, because in addition to the majority of the sculptors embracing Islam, this village is also located in a religious area with several large and influential traditional Islamic boarding (Pesantren) surrounding it. Therefore, it is very natural that the message from the hadith text which prohibits statues, pictures and the like is very familiar to them, butr they are still comfortable and not burdened morally with their daily routine as a Moslem who works as a professional sculptor.

In the end, the deadlock in the relationship between religion and its adherents that seems paradoxical as the relationship between Moslem sculptors and the prohibition doctrine of figurative art, becomes the focus for this research. However, the research is limited to the discussion of sculptures, because in addition to the subjects in this study are the sculptors in the Prumpung Magelang area, also considering the differences of opinion among scholars regarding the 
existence of paintings of living things. This research also does not concern with looking for the essence of the true meaning of the hadith text (fahm al-hadîs) which prohibits the existence of statues, but instead seeks to focus on understanding the creative reasoning model that exists in the minds of Moslem sculptors in Prumpung and its surroundings when responding to the hadith text regarding the prohibition of making statue.

This research is a qualitative by combining field research with literature. In the field, this research was conducted in Prumpung, Tamanagung Village, Muntilan District, Magelang Regency, Central Java, Indonesia, with the research subjects being Moslem sculptors who live in the Prumpung area and its surroundings. The research data were obtained from in-depth interviews with informants consisting of statue's sculptor, community leaders and religious leaders. Observation and documentation related to the location and activities of sculpting the statue were also carried out to support the data and information obtained from interviews with informants.

In practice, this research interviewed informants who had sufficient data and information related to history of the emergence of a statue carving center in Prumpung Magelang. Based on these considerations, the subjects in this study were the moslem sculptor in Prumpung Magelang, which consisted of the studio owner (skipper) and the carvers (workers). The principle of triangulation in determining and considering informants in this study is represented by: First, the group of informants consisting of sculptors, namely: (a) first generation sculptors whose Islamic expression is closer to the Javanese tradition, (b) sculptors who come from among "the santri" and (c) the second generation sculptor who was previously a worker / employee of the first generation sculptor but now has his own studio. Second, the group of informants who come from religious communities (represented by elements of the pesantren) who 'reject' the existence of the statue. Third, the group of informants consisting of community leaders in the Muntilan area.

\section{Results and Discussion}

G.R. Hawting (2001) explains the change in the function and concept of sculpture, from non-theological objects to theological nuances. Furthermore, Hawting examines the origin of the term 'idol' (așnām) which is attached to statues which are used as objects of 
worship by the ignorant community (jāhiliyyah) of Makkah, so then the course of the history of Islamic civilization, statues and images are categorized as forbidden because they are considered as embodiments of idols. Hawting explained that the embedding of the concept of an idol to the statue actually does not originate directly from the Qur'an, but is born from an intra-monotheist polemic and more as an affirmation of Islam as a monotheistic religion, a religion that continues the teachings of Abraham's tauhid. Where Islam was born and developed in a community that adheres to polytheism, namely the land of Mecca, while on the other hand there are several monotheistic communities (followers of Millah Ibrahim, Christians and Jews) that are already established around Makkah (Donner \& Hawting 2001).

Khalil Athamina (2004), explains the process of change in society around Makkah, from communities that were previously monotheists (the people of Prophet Ibrahim a.s.) turned into polytheists. In his investigation, there were two reasons for this, namely (1) the interests of the Makkah bourgeoisie in order to maintain its hegemony, both social hegemony and economic hegemony, and (2) trade interests that had been developed between the tribes (Athamina 2004).

Julie Spraggon (2003) describes the long history of iconoclasm in Britain during the civil war (Spraggon 2012). Natalie N. May (2012), explores the notion of iconoclasm. According to him, this understanding is a term that actually originates from the Byzantine civilization, but in its development this term is so attached to the Protestant tradition that it strictly prohibits images and statues (including the prohibition of depicting God-Jesus) whether during worship (in church) or not (at home ) (May 2012). In further research, Hanspeter Schaudig from the University of Heidelberg entitled his writing both emphasized that iconoclasm is often a political instrument, so it is very vulnerable to be used for certain political purposes.

The only field study that discusses the relationship between statue, sculptor and the religion, especially in Indonesia, is the research by 
Khafidhotus Soidah (2014). In this research, she seeks to understand the paradoxical phenomenon, namely a community that normatively includes devout Moslems, but has a profession as a sculptor. In his search, she found that they never considered their activities as sculpture carvers to be contrary to Islamic doctrine, what they were doing was nothing more than an effort to meet economic needs alone (Soidah, 2014). But unfortunately, this research does not specifically utilize social analysis in exploring the facts behind this paradoxical phenomenon so as to produce a clear map of the relationship between sculptors - Islamic doctrine. This void will be completed in this research using the reception theory approach.

This research was designed in the form of a living study by utilizing the reception theory as a medium of analysis in order to map the reasoning model of Moslem sculptors in Prumpung Magelang when responding to the prohibition of sculpting doctrine which originates from the hadith texts. Etymologically, the word reception comes from the Latin language, recipere which is interpreted as acceptance or greeting of the reader (Ratna 2015A, 165), or it can also be interpreted as the art of receiving something (Rafiq, 2014, 144). While the understanding of reception terminologically is a study of beauty that is based on the reader's response to literary works (Pradopo 2007, 7). More broadly, reception is defined as text processing, ways of giving meaning to the text, so that it can respond to the text. The intended response is not done between the work and the real reader, but rather the reader as a historical process, the reader in a certain period known as the synchronic and diachronic model historical approach (Ratna 2015A: 167).

In addition to the reception theory, this study also uses Umberto Eco's semiotic-communication structure model in order to reconstruct the orthodoxy process of the hadith text originating from the Prophet PBUH that becomes a doctrine finally (when accepted by the common people). This process is identified through the semioticcommunication concept of the Umberto Eco model which consists of source, transmitter, signal, channel, receiver, message and destination. 
Therefore, this study does not aim to explore the true meaning of texts on the prohibition of sculpture (as in the study of fahm al-hadî̀) which mostly relies on semiotic-hermeneutic studies. On the other hand, this study provides the widest possible opportunity for the reader (audience) to respond the hadith text up to be realized in the realm of culture and traditions of the Moslem community in Prumpung Magelang who work as a sculptor.

\section{Statue in Islamic History and Civilization}

Several terms are operationally used in the Islamic treasures to designate the word statue, namely the word timŝāl (or tamāŝil in the plural), șūrah (plural = șuwār), șanam (plural = aṣnām) and the word waŝan (plural = auŝān). The last two words, namely the word șanam and the word waŝan are two terms that are usually operationalized specifically to refer to statues (but are more often used to refer to idols) (al- Kalbī 1995, 27). Lexically, the two are distinguished based on the raw materials in making them, if the sanam is made of metal, then the waŝan is made of stone or wood (Florella 2007, 255), or if it follows Ibn al-Kalbi's opinion, if the statue is human and made of gold, silver or wood it is called șanam, but if the raw material is made of stone it is called Waŝan (al-Kalbī 1995, 27).

In the Islamic perspective, the origin of the statue can be traced into three phases, namely the phase before the Prophet, the phase of the Prophet's time, and the phase after the Prophet. The first phase can be pulled back from Prophet Adam up to Prophet Isa. In this phase, the statue was made for the first time which was during the time of Prophet Shîs who is the son of Prophet Adam (the younger brother of Qābil and Hābil). The statue depicting five figures at that time, namely Wadd, Suwāĝ, Yaĝriŝ, Ya'ūq and Nasr, is the work of descendent from Qābil (al-Kalbī 1995, 51). Initially, the statues were made to commemorate five figures who were highly respected by the community at that time who had died.

Ibn al-Kalbī, in Kitāb al Așnām, explains how the origin of the five statues was converted as idols. That in the first period since the five statues were made, the community still treats the five statues as their 
original purpose, namely simply as monuments so that the next generation will remember and imitate the examples that have been exemplified by the five figures. However, in the second generation, the community has begun to overdo it in respecting the five statues. And finally starting from the third generation, the five statues have become idolatrous, the practice of religious rituals is also centered on the worship of the five statues (al- Kalbī 1995, 51).

Da'wah to the community of his descendants Qābil by the Prophet Idris (Another name for him is Hanūkh, son of Yarud bin Mahlā-îl bin Qainan bin Anūsy bin Prophet Syî̂), until then the preaching was continued by Prophet Noah still unable to stop the paganism. After the occurrence of flash floods during the time of the Prophet Noah, which left only Noah's followers, Those who believed, until the succession of messengers to the sending of Prophet Jesus, still left certain communities that embraced paganism like the followers of Prophet Ibrahim, the people of Prophet Musa when he met Samiri, as well as the followers of other prophets to the Arab Jahiliyyah before the Prophet Muhammad. In this first phase, the existence of the statue is almost inseparable from the concept of idols itself due to the existence of statues which are used as the main medium in rituals idolatry. However, what is interesting in this first phase is that there is no prohibition in the Shari'a of the previous Prophets in relation to the existence of statue, as narrated in Qs. Saba': 13 concerning Prophet Sulaiman who placed several statues in his royal infrastructure building designs.

In the second phase, namely during the time of the Prophet Muhammad and his companions, divided into two periods namely the Mecca period and the Medina period. In the first period, he focused on fighting against the social system of Arab society based on paganism symbolized by various kinds of statues scattered throughout the Arabian Peninsula with the center of ritual and worship in Mecca. Hence, it was during the period of the Makkah, the Prophet do not need to distinguish between the concept of idols on the one hand, and the concept of statues on the other. This can be seen when 
mentioning the words șanām (which lexically can be interpreted as statues) and awŝān (translated as idol), but practically the two terms often overlap and are used to describe the phenomenon of idolatry.

However, in the second period, namely in Medina especially after the Fath Makkah, the concept of shirk and the existence of a statue were divided into two different concepts. In its journey, the practice of shirk does not have to be related to statues, as well as the existence of statues was not have to be related to the concept of idols. The separation between the two existences appeared during the Prophet issued a prohibition against the existence of figurative art (whether in the form of paintings or sculptures) which had no direct connection with idolatry, either in the public or private sphere. As seen in several editors of the hadith, the prohibitions against statue are no longer caused by their idolatrous function, but because it resembles God's creation (an-Nawawi n.d., XIV/8191).

The third phase, started from the era of the first generation of Islam, namely the generation of sahaba (and also tabi'inn) up to now. In this phase, the distinction process between the statue and the syirk concept reaches its peak which is marked by the autonomy of each of the two concepts. The concept of Syirk is increasingly detaching itself from the image of sculpture, while the existence of sculpture is increasingly moving away from theological problems as the embodiment of idols, so in the end it is no more than just a pure art (Mustofa 2021, 62-65).

\section{The Prohibition of Statue in Islam}

As has been explained in the previous discussion, that the view of the Shari'a on the existence of statue (and other figurative arts) during the prophetic period before the Prophet Muhammad, its existence is still tolerable as long as it is not misused as an object of ritual idolatry. Literally, evidence of Sharia tolerance for the existence of a statue is clearly recorded in the QS. Saba': 13, which is described how Prophet Sulaiman puts a various statues (tamâsîl) in the design of the kingdom's infrastructure development. Some commentators explained that these statues functioned as monuments to 
commemorate the religious people of that time with the hope that the next generation could imitate and emulate the life stories of those (Az-Zamakhsyarī 1998,V/111).

From this verse, we can actually make a conclusion that the prohibition of figurative art does not come directly from the text of the Koran, but from the hadith of the Prophet. It was found that there were not less than 140 hadith texts that literally prohibit them. the existence of figurative art, whether it is functioned as an idol or merely as decoration. In the Kitāb al-Minhāj Syarḥu Șạịh Moslem ibn alHajjāj for example, Sheikh Abu Zakariyya an-Nawawi explains that there are several narrations with different editors, with the same moral message that every painter (especially a sculptor) will get tormented in the afterlife. Therefore, Islam prohibits the painting (and statue) of living things, even categorized as a grave sin caused by imitating and resembling God's creation (an-Nawawi, n.d, XIV/81-91).

In other books, such as 'Umdatul Qārī Syarkh Șahīh Bukharī, Badruddin al-'Ainy al-Hanafiy even discussed the prohibition of someone who is a professional as a painter and sculptor. The event was narrated from Ibn Abbas, that someone came to him and offered him a painting of a living being carved by his hand. He explained that his work as a painter / sculptor, meaning that he earns money by selling his chisel products. In this narration, Ibn Abbas firmly refused the offer of the painter / sculptor, while advising that a painter / sculptor of living things like himself, if he does not immediately repent, then in the afterlife will be forced by God to bring his paintings / sculptures to life, even though he is not will be able to do so, therefore God will torment the person with a painful (al-'Ainy AlHanafiy nd, XVIII/159). Wisely, he gave a solution to him that he could continue to work as a painter / sculptor with a note that the object of his painting / sculpture does not resemble a living creature, but can be in the form of objects that do not have a spirit, such as trees, fruits, mountains and so on.

In general, the traditions which prohibit the existence of figurative art are divided into five fragments, namely: (1) The threat of 
punishment on the Day of Resurrection against painters and sculptors who make figurative works of art, (2) Angels don't want to enter a house in which there is a figurative picture and a dog, (3) In Aisyah's house there is a curtain depicting living things, then the Prophet ordered to cut the curtain to make something else (a small pillow), (4) The Apostle of the Prophet in a funeral procession for the body, to destroy the statue, destroy the image and even out the grave, (5) At the Fathu Makkah event, the Prophet do not want to enter the Ka'bah because there are still many pictures and statues. Then he ordered Umar to clean the pictures and idols, only then he was willing to enter the Ka'bah.

Every fragments of the hadith naration above has interesting events to discuss. First, the time of the Prophet instructed through an appeal to his companions to flatten the tomb (grave) and destroy statues and pictures, that this hadith was only narrated by Ali bin Abi Talib so that this hadith is specifically grouped in the hadith ahad. Second, the incident that occurred during the conquest of Mecca especially when the prophet instructs his companions to destroy all the idols around the Ka'bah, as well as the images of the sanctified figures found in the Ka'bah, such as Prophet Isa and his mother Maria. Based on a history that comes from the testimony of al-Azraqi (858 $\mathrm{AD})$ that at the time of the Prophet ordered his companions to erase all the images contained in Ka'bah, while his two noble palms were placed (covering) the two images of Maria and Prophet Isa, he said: "Erase all pictures (that are in the Ka'bah), except for the pictures that are under my palms" (asy-Syarqawi \& \& Ath-Thahlawi 2009, 71).

Negotiations on the Prohibition of Figurative Art

The doctrine of the prohibition of making statue originating from the traditions of the Prophet, as described above, bring out a works of art which later became a characteristic feature of Islamic civilization, namely the art of ornamentation and calligraphy. In the archipelago itself, this prohibition also bring out a new culture and art, namely wayang. As we know, wayang is the result of the creativity of 'ulamā in archipelago who compromise between figurative art and Islamic 
religious doctrine for the sake of da'wah, without having to directly confront the hadith text which prohibits drawing and statue. The concept of wayang is a depiction of a human figure which is illustrated in certain forms and patterns so that it can't be defined as a human (living being).

However, the doctrine of the prohibition of figurative art doesn't always work as it should. In a village called Prumpung, which is located in Magelang Regency, there is a center for sculpting a statue of andesite stone. Interestingly, in this area which is surrounded by several Tradisional Islamic boarding (Pesantren), almost the majority of the sculptors are Moslem, which creates a unique and interesting phenomenon when Moslems living in Prumpung work as sculptors.

Prumpung Village at a Glance: A Statue Center

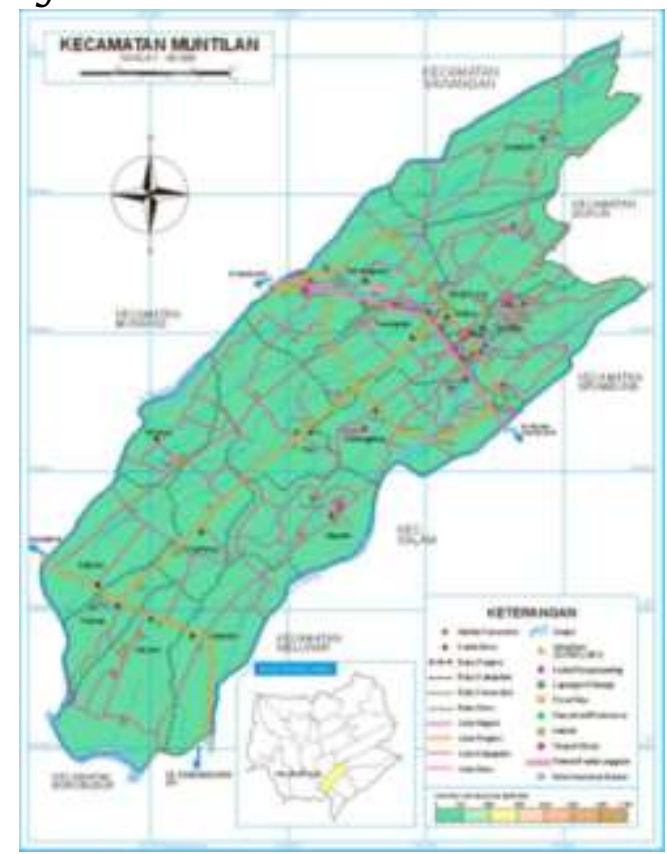

Figure 1. Regional Map of Muntilan District

The Prumpung area which is the object of this research is under the governance of Tamanagung Village, Muntilan District, Magelang Regency, central java, Indonesia. Muntilan sub-district itself is a 
bustling small city in Magelang, with the existence of a shopping area where the majority of owners are Chinese descendants, a very large traditional market and an inter-provincial bus terminal that is located right in the middle of the city, Muntilan is the busiest small town in Magelang Regency, even with Mungkid City itself. as the capital of the district.

Prumpung Village is special compared to other villages, due to its position as a stone craft center as well as a transit tourist destination for both domestic and foreign tourists who want to travel to Borobudur temple. The tourists who transit will be spoiled by a variety of andhesite stone handicraft products, ranging from mortar, floor traps, mortar (stone tools for pounding rice), ornaments installed as interior or exterior, as well as statues / statues, either animal and human statues of various sizes.

Before becoming the center for stone sculpture crafts, namely before the 1950s, the majority of Prumpung residents' livelihoods were farming (around 80\%), while the rest (20\%) were stone carvers, known at that time as jlogro, because at that time the production of stone handicrafts was only limited to a gravestone, umpak (a stone designed as a wooden plinth for a house), cowek (a stone for spices) and a trap stone (a square stone which is usually used as the floor of a temple courtyard).

Stone carving to become a form of statue began around 1958, with the first statue product in the form of a Buddha head pioneered by Mr. Kasrin and Mr. Joyoprono, two people who are still relatives. This statue was bought by an antique dealer from Jogja. Starting from the sale of the Buddha's head statue, the statue carving industry in Prumpung is getting bigger and bigger, both in terms of the number of industrial entrepreneurs and in terms of production variants. Of the number of stone craft business actors no less than 500 stone carving workers who depend on their economy through handicrafts made of andhesite stone, even the stone craft industry has developed outside the Prumpung area, almost evenly around the Muntilan sub-district. 
Meanwhile, in terms of product variants produced are also increasingly diverse, recorded in the list of orders that have been done by one of the sculpture business actors from 1957 - 2000, there are countless numbers, but from the many works, they can be divided into three types, namely ( 1) form of statues, (2) form of miniature temples, and (3) gates (one of his works is a monument or border gate between Jogja-Magelang which is located west of the Krasak bridge). In terms of coverage, the products of stone handicrafts in this region have also entered many foreign markets, either as souvenirs or for spiritual needs, such as making miniature temples in Thailand, Laos and Vietnam.

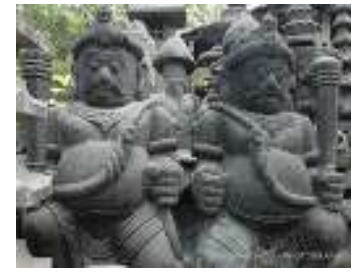

Figure 2. Statues

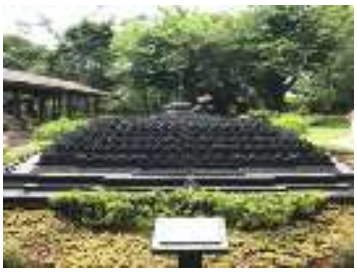

Figure 3. Statues

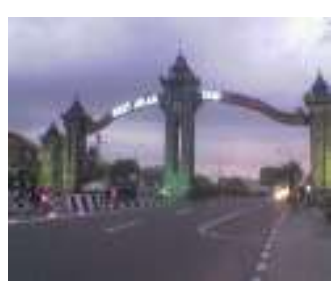

Figure 4. Statues

Another uniqueness that can also be found in Prumpung village is the number of statue carvers who are predominantly Moslem. This becomes unique and interesting when on the other hand the doctrine in Islamic teachings has prohibited its adherents from interacting with the existence of statues, either as sculptors or as collectors. From the statistical aspect, the number of sculptors who embraced Islam can be seen from the following composition of religions embraced by Prumpung residents:

It should also be noted, that the Islam of the sculptors in Prumpung is not just a formality. This can be seen from the several social positions held by the sculptors in their respective communities, ranging from those who already had pilgrimages, mosque administrator, elders of routine recitation groups, Ansor-NU activists, Muhammadiyyah members up to salafi group sympathizers. Although of course, it does not rule out that there are several groups of sculptors who are still categorized as abangan. Being a devout Moslem on the one hand as well as a profession as a sculptor on the other hand, when 
viewed from the aspect of normative piety is certainly very ironic and paradoxical, but sociologically this reality is very interesting to study in depth because there are areas of study that have not been clearly deciphered. related to the relationship between religion and culture, especially when the community as an audience in the profane area interacts with sacred religious texts.

Table. 1. Population Data by Religion in Tamanagung Village

\begin{tabular}{ll}
\hline Religion & Total \\
\hline Islam & 10.452 \\
Kristen & 81 \\
Katholik & 175 \\
Hindu & 5 \\
Buddha & 16 \\
Konghucu & 0 \\
Aliran Kepercayaan & $\mathbf{1}$ \\
Total & $\mathbf{1 0 . 7 3 0}$
\end{tabular}

Source: Department of Population and Civil Registration of Magelang Regency, 2019

From Hadith Texts Up To Doctrine.

Dictum of the Prophet that reaches Moslems today (as the audience) is not a simple process, because there are so many parties involved in it and the process is very long. Through Umberto Eco's semiotic-communication scheme, the parties involved consist of three parties, namely (1) the Prophet Muhammad PBUH, as the source of the emergence of the message, (2) the narrators of the hadith as the party conveying the message from the Prophet, and (3) us as the recipient of the message (audience).

The messages conveyed by the Prophet requires a transmitter, namely narrators of hadith, because Moslems as the recipients of the message have never been able to meet the Prophet as the source of the message. The communication model that is built between the parties involved also uses different models, if the communication of the Prophet with his companions (as one of the transmitters) using spoken language (verbal), the communication used between narattors 
is different, some are narrated verbally, but also not a few are narrated through writing (Isnaeni 2014,40).

Furthermore, when the hadiths have been recorded neatly in the main hadith books (channel) and reach the first audience (or the receiver in Eco's term) then at least two problems arise, namely: (1) Moslems, as audiences only meet text not with the 'owner' of the text, namely the Prophet. Oral utterances (the hadith of the Prophet which were conveyed to the Companions) which have been translated into written form have created a state called 'context free' or 'independent discourse'. It cannot be directly questioned or debated as the utterance was when it was still in oral form, because when it has become a written discourse, it has been released from the author (Walter J 2013,117).

The next problem is: (2) Receiver or message receiver (the first audience) which is limited, because apparently not everyone can access the text. This means that only certain individuals can access the text. If we use Kartodirjo's perspective on the existence of elite groups in the structure of society (Kartodirjo 1983,vii), then the limited group or group that can access the existence of the hadith text is a religious elite group consisting of Moslem scholars and intellectuals, scholars, Kyai and Ustadz (Miftah 2005,169), or the santri group if we want to use Geertz's social group division.

This elite group, with their scientific authority, will carry out a semiotic-hermeneutical process on the hadith texts about the statue in the form of interpretations, ihtisar or even sharia written in volumes of books. For example, the explanation that has been done by Badr adDīn al-'Ainī al-Ḥanafí, the author of the book 'Umdah al-Qārī Syarh Sahịh al-Būkharī when giving an explanation of a hadith narrated by Aisyah about the prohibition of the Prophet. In his explanation, after he quoted various opinions from other scholars, he conveyed his view that 'illat is against the reluctance of angels to enter a house because the existence of the image / painting / statue is absolute without any exceptions. (al-'Ainy Al-Hanafiy, nd: XVII / 374-377). 
Another example can also be found in aṣ-Ṣābūnī interpreting the Q.S. as-Saba': 13 regarding the construction of infrastructure carried out by Prophet Sulayman. where one of what he did was placing statues of pious people (the saints) in the mosque as one of the ways of Prophet Sulayman to set an example for his people to always remember their piety and goodness. In his discussion of this verse, he placed it in the chapter that discusses the law of sculptures and images. In that chapter, in detail and at length, Aș-sābūnī discusses the arguments in the form of traditions which ultimately forbid the existence of images and statues (in the form of living things). Furthermore, he continued with a discussion of the 'illah (causative factor) prohibition of images and statues for Moslems, that is, because they resemble God's creation (Aș-Sābūnī 1981, II / 408-409) and as a way of entering into communion practices of God. This is because nations that adhere to pagan belief systems originate from their habit of collecting and admiring various paintings and sculptures.

Like a finished product, the doctrine as a result of the reading of the scholars is then accepted by the public at large. A common people just need to accept, obey and practice it according to their respective abilities and capacities. The common people ( Moslems sculptor ) are included in the destination category (second audience) in Umberto Eco's communication scheme above.

Moslem Sculptor's Negotiations and Compromises on the Prohibition of Sculpting Doctrine

As the second audience, the Moslem sculptors at Prumpung Magelang had never met directly with the hadith texts as the first audience, this was due to their limited ability to access the hadith texts. The sculptors only met the reading results of the ulama (the first audience) in the form of a doctrine which of course had the potential to experience reduction. This means that the first audience consisting of scholars, is an agent who is obliged to communicate with the common people (the second audience) so that the message contained in the hadith text can be digested more easily by the audience. Simplifying or adding to the messages contained by the text during 
the communication process is certainly something that cannot be avoided, because there is a wide enough gap between the structure of text that is built up in the hadith editorial (regarding the prohibition against the existence of a statue) and actions. which is influenced (structured act) by the culture and culture that surrounds the sculptors (Iser 1987,35-38), namely tradition and reasoning of Javanese culture. Religious messages in the form of doctrine are conveyed to the sculptors to be responded and realized by the sculptor in the social and cultural structure in which he lives.

Regarding the prohibition against figurative art based on hadith narrated from various sources, as described above, textually he does not distinguish whether the statue is functioned as an idol or purely as a work of art. However, the doctrinal structures that reached the second audience (sculptors) underwent various adjustments after being conditioned by the Javanese cultural systems and traditions in which they lived. These adjustments surfaced during an interview with the informant who consisted of several Moslem sculptors in Prumpung Magelang. Whereas from their perspective, the doctrine of prohibiting making statues for Moslems is closely related to the prohibition of worshiping idols in Islam. That is, what becomes the object of the prohibition of the doctrine is not the material of the statue but the conception of the person (society) towards the statue by making it a deified idol. Thus, the prohibition has absolutely nothing to do with the existence of statues as material that has never been made to be idolized and deified in the conception of Javanese society, like the statues they carve.

Therefore, they have enormous scope for making creative compromises in the philosophical realm, very genuine and unengaged. Their ability to dialogue and compromise between doctrine and culture, the two aspects that formally face each other, cannot be separated from the horizon of their thinking as Javanese, who (a) have the concept of sangkan paraning dumadi, sociologically Javanese society (b ) have no historical experience as a pagan (Sunyoto 2012: 12). 


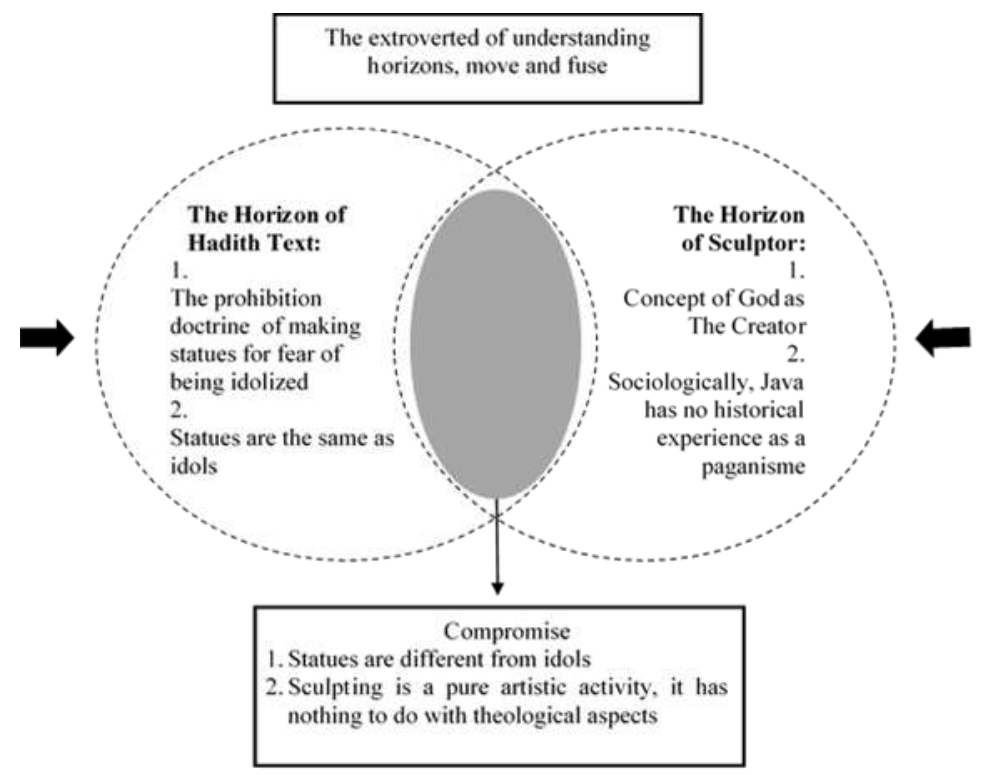

Figure 5. Text's Horizon and Sculptor's Horizon

In certain conditions, this horizon may not be accepted by (1) communities that have historically had experience with paganism, such as the Arabs, or even (2) by some elements of Javanese society themselves due to differences in tradition and culture, for example, in certain Moslem circles who have consciously alienated themselves and their thoughts from the culture and traditions of Javanese society (Mustofa 2021, 236). This is because society's understanding of a phenomenon so as to form a horizon that transcends the subjectivity of each individual in that society, enabling it not only to help understand the phenomenon, but also to function to reject it.

From this, we can understand that the thinking horizon possessed by Moslem sculptors in Prumpung Magelang is not only a reconstruction of the past understanding represented by the doctrine of the prohibition of sculpture, but also an integration (fusion) between the past horizon and the present horizon of the reader (Hardiman 2015, 163), namely the Moslem sculptors in Prumpung Magelang who happened to be born and raised within the scope and influence of the Javanese tradition which is very thick. 
The principle is that a person's horizon of understanding is dynamic and not isolated, therefore there is no sterile horizon or is not influenced by other, different horizons. The process of understanding itself never moves outside the horizon, but moves on and is within it, meaning that the understanding of the Moslem sculptors in Prumpung Magelang towards the existence of the statue was not a fabrication because their understanding was 'submissive' to the history (tradition) that surrounded it as Javanese. The meeting of the sculptor's horizon with other horizons (the doctrine of the prohibition of making sculptures) ultimately results in new understandings in the form of 'compromise', because understanding (verstehen) is always a process that involves tension (dialectics) of various horizons or in other words it is always an amalgamation (fusion) of perceived horizons of themselves (Hardiman 2015, 163). The fusion itself is not the assimilation of one horizon into another, but an intersection between horizons (win-win concept).

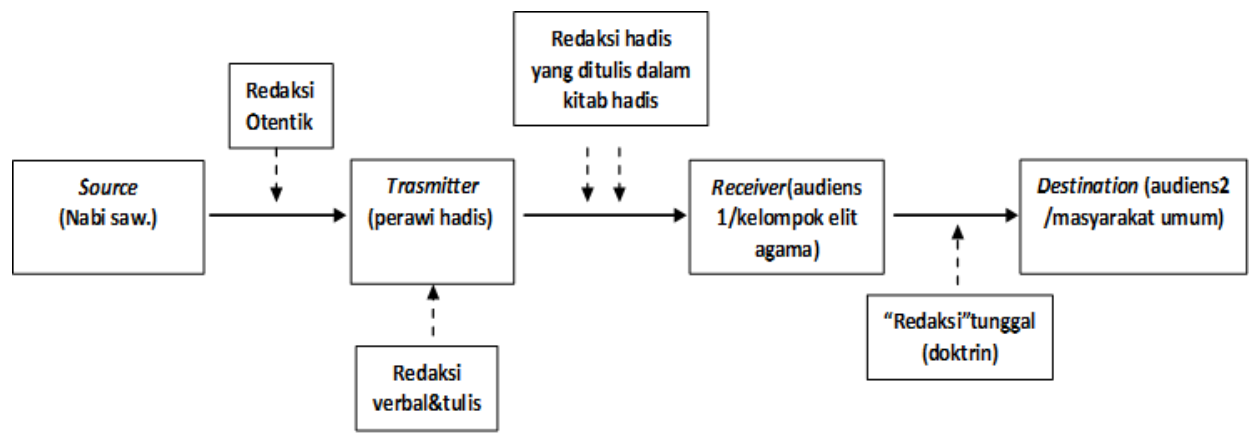

\section{Figure 6. Eco's Schematic About Semiotics of Communication}

The compromise made by these Moslem sculptors was because it was in a philosophical area, so materially there did not appear to be any changes in the sculpting work. In material terms, the resulting sculptural works remain in the form of figurative statues, as is common with other sculptures. However, the effect that many parties may not realize from their compromise model is the creation of 
community harmony in relation to the public's acceptance of the existence of the Prumpung Magelang area as a center for the sculpture carving industry, which at the beginning of its appearance had become a polemic in the community. The harmony isn't born suddenly but through the intensity of the dialectic and internal communication that is built consciously by the moslem sculptors.

The view of Moslem sculptors on the existence of statues as mentioned above, is of course very vulnerable to criticism, especially from a textual approach point of view because the responses of the sculptors are considered reductive so that they limit the doctrine of the prohibition of figurative art only to the aspect of idolatry. In fact, as before, the text of the hadith that explains the prohibition of painting and making sculptures in the form of living things is very large, ranging from the traditions that order the destruction of various forms of statues that function as idols, to orders and prohibitions for simply drawing or collecting paintings. in the form of living things. This means that the prohibition narrated by the hadith text is not limited to idolatrous statues as the response of the Muslim sculptors in Prumpung, but also includes the existence or existence of the statue itself, whether it is misused as an object of worship or only functions as an object of beauty and art.

Regarding the simplification of the views of the Moslem sculptors mentioned above, that the doctrine of the prohibition of statues is only related to the concept of idolatry (even though there are several doctrines of prohibition relating to images and sculptures), this can certainly be explained through Eco's semiotic communication scheme as already mentioned, as follows.

From the communication scheme of the Eco model above, it is illustrated that the hadith text as a source of doctrine against the prohibition of this statue has two different audiences, namely (1) a receiver and (2) a destination. This first audience was limited, because apparently not everyone could access the text. This means that only certain individuals can access the text because of differences in scientific capacities, including a religious elite group consisting of 
Moslem scholars and intellectuals, scholars, kyai and ustadz (Miftah 2005: 169), or at least from the group of santri. Meanwhile, the second audience which is positioned as a destination is the wider community (layman), namely audiences who do not have sufficient ability to access primary sources in the form of hadith text, so they can only consume the results of the hermeneutic - semiotic process from the first audience or receiver in the form of finished products, namely in the form of formal laws or in the form of doctrines. It is in the second audience position (destination) where the Moslem sculptors at Prumpung Magelang are located, so that they only know globally (ijmali) the doctrine of the prohibition of statues, namely the prohibition of idolizing something, whether it is in the form of a statue or otherwise.

In this context, the doctrine of the prohibition of sculpting that develops in society is closely related to the function of idolized statues. This occurs because the prevailing doctrine in society has its own practical logic, namely the necessity of providing certain reasons behind a prohibition. These objective realities cannot be separated from the communication efforts built by the receiver to the destination so that divinity messages from the hadith text can be easily conveyed and digested by the common people.

Based on the description above, it becomes understandable when the doctrine of prohibiting the existence of statues is understood by the common people as a form of resistance to all kinds of idolatry practices. Whereas the statues made by sculptors were depicted by the common people as having the same status as the deified idols. In the midst of this view of society, the Moslem sculptors in Prumpung Magelang lived and actualized themselves as an artists who made statues, without having to desacralize and direct confrontation with hadith texts.

Therefore, since the statues that carved by sculptors are not intended for idolatry, they thinks that sculpting is a lawful profession (halal), like other general professions in society, which can bring financial benefits. With this view, the sculptors will continue their 
profession as a sculptor without having to contend with his status as a good Muslim.

\section{Conclusion}

The reception carried out by Moslem sculptors at Prumpung Magelang towards the hadith which prohibits the existence of figurative art, goes hand in hand with the reasoning of thinking that the Javanese people were sociologically not a pagan society, so that they did not have a moral burden on the existence of statues. For them, sculpture has absolutely nothing to do with theological problems, therefore sculpture is positioned purely as a work of art. The view of statues, as the response of Moslem sculptors to the existence of statues, is very natural for ordinary Javanese people, so that the sculpting profession is positioned the same as other halal professions such as being a farmer, trader, teacher and so on. This means that the sculptor's understanding of the statue which is heterodox is the result of an objective dialectic between the horizons of Javanese society when dealing with texts, and not solely because of pragmatic economic needs.

The sculptor's understanding of the doctrine, as described above, is categorized as a heterodox understanding, but the practice of living hadith is not a form of desacralization of the text. The Sculptors only had an intense dialectic with the doctrine as a result of the reading of the ulama (first audience) toward the hadith text. Meanwhile, the position of the hadith text in living studies is not as an object of living actors but only as a source of inspiration, so it is very natural when ordinary people as living actors rarely know exactly the sound of the hadith text. Therefore, the text (hadith) remains sacred because the common people (second audience) as the subject of living practice do not directly contact the text due to its limitations in accessing the hadith texts.

\section{REFERENCES}

al-'Ainy Al-Hanafiy, B. n.d.. 'Umdatul Qariy Syarkh Shahih Bukhariy (o.1; pp. XVII-159). Program Maktabah Syumila NU.

al-'Ainy Al-Hanafiy, B. n.d.. 'Umdatul Qariy Syarkh Shahih Bukhariy (o.1; pp. XVII-159). Program Maktabah Syumila NU. 
al- Kalbī, H. I. M. ibn as-S. 1995. Kitāb al- Aṣnām. Darul Kutub alMisriyyah.

an-Nawawi, A. Z. Y. ibn S. ibn M. n.d. al-Minhaj Syarkhu Shahih Muslim ibn al-Hajjaj (o.1; pp. 81-91). Maktabah Syumila NU.

Aṣ-Ṣābūnī, M. 'Ali. (1981). Rawāi'ul Bayān. Maktabah al-Ghazāli.

asy-Syarqawi, M. A. H., \& \& Ath-Thahlawi, M. R. 2009. Ka'bah; Rahasia Kiblat Dunia (K. Junaidi, Luqman \& Fath (ed.)). MIZAN.

Athamina, K. 2004. Abraham in Islamic perspective reflections on the development of monotheism in pre-Islamic Arabia. Islam Zeitschrift Fur Geschichte Und Kultur Des Islamischen Orients, $81(2)$, https://doi.org/10.1515/islm.2004.81.2.184 184-205.

Az-Zamakhsyarī, A. al-Q. M. bin U. 1998. Tafsīr al-Kasyāf (- (ed.)). Maktabah al-'Abikan.

Caviness, M. H. n.d. Iconoclasme et Iconophobie; Quatre Etudes De Cas Historiques. Diogene-Presses Universitaires de France. https://www.cairn.inforevue-diogene-2002-3-page-119.htm

Donner, F. M., \& Hawting, G. R. 2001. The Idea of Idolatry and the Emergence of Islam: From Polemic to History. Journal of the American Oriental Society, 121(2), 336. https://doi.org/10.2307/6066o8

Florella, S. 2007. The word $\mathrm{s} \mathrm{lm} / \mathrm{snm}$ and some words for "statue, idol" in Arabian and other Semiticlanguages. Proceedings of the Seminar for Arabian Studies, 37.

Hardiman, F. B. 2015. Seni Memahami: Hermeneutika dari Schleiermacher sampai Derrida. Yogyakarta. PT Kanisius.

Iser, W. 1987. The Act of Reading: A Theory Of Aesthetic Response ((ed.)). The Johns Hopkins University Press.

Isnaeni, A. 2014. Historisitas Hadis Dalam Kacamata M Mustofa Azami. Jurnal EPISTEME, 9(2).

Kartodirjo. 1983. Elit Dalam Perspektif Sejarah (Kartodirjo (ed.)). $\mathrm{LP}_{3} \mathrm{ES}$.

Komaroff, L., \& Allen, T. 1991. Five Essays on Islamic Art. Journal of the American Oriental Society, 111(3), 611. https://doi.org/10.2307/604298 
May, N. N. 2012. Iconoclasm and text destruction in the ancient Near East and beyond. In Iconoclasm and Text Destruction in the Ancient Near East and Beyond (Issue 8). https://oi.uchicago.edu/pdf/10_11_Iconoclasm.pdf

Miftah, F. 2005. Perilaku Sosial Politik Kyai Di Tengah Masyarkat Transisi; Kasus Di Wilayah Cirebon Dan Bandung. Jurnal MINBAR, XXI(2).

Mustofa, A. 2021. PATUNG ANTARA DOKTRIN DAN TRADISI (Resepsi Pemahat di Prumpung Magelang Terhadap Hadis Pelarangan Patung). Universitas Islam Negeri Sunan Kalijaga Yogyakarta.

Pradopo, R. D. 2007. Beberapa Teori Sastra; Metode Kritik dan Penerapannya, (- (ed.)). Pustaka Pelajar.

Ratna, N. K. n.d.-a. Estetika Sastra dan Budaya (- (ed.)). Pustaka Pelajar.

Ratna, N. K. n.d.-b. Teori, Metode Dan Teknik Penelitian Sasatra: Dari Strukturalisme Hingga Post Strukturalisme-Perspektif Wacana Naratif (- (ed.)). Pustaka Pelajar.

Rofiq, A. 2014. The Reception of the Qur'an in Indonesia: A Case Study of the Place of the Qur'an in a Non-Arabic Speaking Community. The Temple University Graduate USA.

Soganci, Ismail, O. 2004. Islamic Aniconism: Making Sense of a Messy Literature. Marilyn Zurmuehlen Working Papers in Art Education, 1. https://doi.org/10.17077/2326-7070.1376

Soidah, K. 2014. Teologi Pemahat Patung; Pemahaman Teologi Pemahat Patung Tentang Ke Esaan Allah di Dusun Jatisumber Desa Watesumpak Kecamatan Trowulan. UIN Sunan Ampel Surabaya.

Spraggon, J. 2012. Puritan Iconoclasm during the English Civil War. In Puritan Iconoclasm during the English Civil War. https://doi.org/10.1017/upo9781846151408

Sunyoto, A. 2012. Atlas Wali Songo. Mizan Media Utama.

Walter, J, O. 2013. Kelisanan Dan Keaksaraan (I. Rika (ed.)). Gading Publishing. 